\title{
KONFLIK PEMBEBASAN LAHAN DI WILAYAH TANAH ADAT MASYAKARAT HUKUM ADAT DALAM KONSENSI PERTAMBANGAN MINERAL DAN BATUBARA
}

\author{
Erika \\ Kandidat Doktor FH UGM Yogyakarta \\ Notaris \& PPAT di Samarinda Kalimantan Timur \\ Dosen FH Universitas 17 Agustus Samarinda Kalimantan Timur \\ Email : erika_notaris@yahoo.com
}

\begin{abstract}
ABSTRAK
Dalam UUPA menyatakan hukum agraria nasional berlandaskan hukum adat, dalam hal ini hukum adat yang di konstruksi oleh hukum negara. Undang-Undang Pokok Agraria menunjukan konsep pluralisme dengan membahas konstruksi undang-undang pokok agraria terhadap hukum, menunjukan bahwa dalam relasi antara hukum negara dan hukum adat sangat dimungkinkan upaya mengkontruksikan atau mendekonstruksikan hukum adat sesuai kepentingan negara. Hal yang sangat tepat menyelesaikan konflik dengan menggunakan adat lokal atau kearifan lokal yakni berperannya lembaga karena selama ini sudah membudaya dalam masyarakat. Oleh karena kearifan lokal adalah sesuatu yang sudah mengakar dan biasanya tidak hanya berorientasi profit semata, tetapi juga berorientasi sakral sehingga pelaksanaannya bisa lebih cepat dan mudah diterima oleh masyarakat. Dengan adat lokal ini diharapkan resolusi konflik bisa cepat terwujud, bisa diterima semua kelompok sehingga tidak ada lagi konflik laten yang tersembunyi dalam masyarakat.
\end{abstract}

Katakunci : pluralisme, hukum adat, kearifan lokal

\begin{abstract}
In the UUPA it states that national agrarian law is based on customary law, in this case customary law which is under construction by state law. The Basic Agrarian Law shows the concept of pluralism by discussing the construction of the basic agrarian law against the law, indicating that in relation between state law and adat law it is possible to construct or deconstruct customary law in the interests of the state. It is very appropriate to resolve the conflict by using local adat or local wisdom that the role of the institution because it has been entrenched in society. Because local wisdom is something that is rooted and usually not only profit-oriented alone, but also sacred-oriented so that its implementation can be more quickly and easily accepted by the community. With local custom it is expected that conflict resolution can be quickly realized, can be accepted by all groups so there is no longer latent concealment hidden in the community.
\end{abstract}

Keywords: pluralism, customary law, local wisdom

\section{Pendahuluan}

Bahwa Negara Kesatuan Republik Indonesia melindungi segenap bangsa Indonesia dan seluruh tumpah darah Indonesia, memajukan kesejahteraan umum, dan menegakkan hak asasi setiap warga negara melalui upaya penciptaan suasana yang aman, tentram, tertib, damai, dan sejahtera, baik lahir maupun batin sebagai wujud hak asasi setiap orang atas perlindungan agama, diri pribadi, keluarga, kehormatan, martabat, dan harta benda, bahwa perseteruan dan 
benturan antar kelompok masyarakat dapat menyebabkan konflik sosial yang mengakibatkan terganggunya stabilitas nasional dan terhambatnya pembangunan nasional.

Tantangan yang besar yang dihadapi oleh bangsa Indonesia dalam membangun bangsa adalah mempertautkan kepentingan masyarakat yang berbeda, karena terdapat pluralisme dalam struktur dan budaya masyarakatnya. Perbedaan etnis, perbedaan keyakinan relegius, perbedaan pandangan terhadap alam dan lingkungan seringkali menjadi faktor penyebab kegagalan membangun suatu bangsa. Berbagai peristiwa konflik komunal komunitas adat atau kerusahan sosial akibat berbeda pilihan hukum dalam sektor agraria di berbagai tempat di tanah air menujukan bahwa kasuskasus hukum membutuhkan penjelasan secara sosiologis antropologis yang di latarbelakangi alasan masyarakat kurang mendapat peluang untuk mendapatkan akses hukum dan keadilan sosial (Saidin, 2000;32).

Di Indonesia kompleksitas persoalan hukum, politik hukum dan wajah penegakan hukum dalam kerangka pemanfaatan lahan tidak hanya sebagai suatu hal substantif melainkan berkenaan pula dengan masalah prasyarat atau prosedur memperoleh hak dan kesadaran hukum masyarakat (Husni, 2009;1). Pemahaman sempit memandang bahwa hukum hanya semata-mata bersifat normatif tanpa memperhatikan faktor dari luar yang mempengaruhi pembentukan dan bekerjanya hukum akan membuat frustasi bilamana menghadapi kenyataan bahwa keberlakukan dan penegakan hukum tidak sesuai dengan tujuan dan maksud dibentuknya hukum itu sendiri. Membuat hukum bekerja dengan lebih baik dan memberikan keadilan bagi semua warga masyarakat merupakan salah satu tugas kolaborasi pemerintah dan seluruh masyarakat Indonesia. Era reformasi terbuka peluang agar lembaga pemerintah dan lembaga hukum dapat melayani kepentingan masyarakat dengan baik bersamaan dengan upaya pembaharuan hukum oleh pemerintah dan penghapusan pembatasan peran politik masyarakat.

Pola umum rencana strategis pembangunan hukum yang dapat dijadikan landasan bagi penataan hukum nasional yang meletakan pola pikir yang mendasari penyusunan sistem hukum nasional yang berintikan komponen materi hukum (legal substance), aparatur hukum (legal struckture) dan budaya hukum (legal culture) serta didukung sarana dan prasarana (Rahardjo, 2009). Pembangunan hukum haruslah diperbaharui sektor-sektor lain seperti ilmu hukum dan ide-ide hukum melalui proses pendidikan dan pemikiran akademik, pembaharuan hukum haruslah di dekati dengan mengubah sistem pendekatan yang sempit (legalistik) menjadi pendekatan yang lebih sistematik, holistik dan terpadu (Rahardjo, 2009). Untuk dapat melakukan kajian yang holistik terhadap hukum dan kenyataan sosial maka diperlukan suatu pendekatan empiris yang memungkinkan untuk dapat dilakukan pengamatan terhadap beroperasinya hukum (Irianto, 2000;32). Dengan melihat komponenkomponen dari sistem hukum yang saling mempengaruhi satu sama lain tersebut, maka dapat dikaji bagaimana beroperasi hukum dalam keadaan sehari-hari. Hukum adalah bagian dari kebudayaan dan masyarakat, oleh karena itu tidak mungkin mengkaji hukum secara terisolasi, tanpa memperhatikan kekuatan-kekuatan sosial yang ada dalam masyarakat. 
Secara khusus budaya hukum adalah bagian dari kekuatan-kekuatan sosial tersebut, yang memberi masukan, menjadi pengerak, dan selanjutnya memberi output kepada sistem hukum. Friedman berpendapat kekuatan sosial harus terus menerus dipengaruhi sistem hukum, kadang-kadang ia merusak, memperbaharui, memperkuat, atau memilih untuk menampilkan segi-segi tertentu (Irianto, 2000).

Berkenaan dengan konflik Pembebasan Lahan Atas Tanah Ulayat Masyarakat Hukum adat yang di lakukan oleh perusahaan sebagai pelaku investasi yang menjalankan kegiatan usaha di bidang pertambangan mineral dan batubara, hal ini dikarenakan saat ini semakin meningkatnya kebutuhan akan tanah untuk keperluan pembangunan. Sementara tanah Negara dapat dikatakan hampir tidak tersedia lagi. Isu mengenai eksistensi hak adat menimbulkan banyak persepsi, paling tidak dapat dikatakan ada dua pandangan mengenai isu tersebut, yakni di satu pihak terdapat kekhawatiran bahwa hak adat yang semula tidak ada kemudian dihidupkan lagi. Di lain pihak, ada kekhawatiran bahwa dengan semakin meningkatnya kebutuhan akan tanah, akan semakin terdesak hak adat yang keberadaanya dijamin oleh Pasal 3 UUPA (Sumardjono, 2007;23). Pengakuan eksistensi oleh UUPA merupakan hal yang wajar karena hak adat berserta masyarakat hukum adat telah ada sebelum terbentuknya Negara Republik Indonesia jauh hari sebelum lahirnya hukum pertanahan nasional kita. Pasal 3 Undang-Undang Pokok Agraria menegaskan pengakuan tersebut dan sudah dijelaskan bahwa dalam ketentuan pasal ini diakui dengan pembatasan-pembatasan tertentu, yakni mengenai eksistesi dan pelaksanaannya. Di kalangan masyarakat awam pun pengertian dasar tentang hak tanah adat beragam, ada sebagian masyarakat yang menafsirkan hak adat sebagai kepemilikan yang mengarah kepada kepemilikan individual, sedangkan sejatinya hak adat itu adalah hak bersama seluruh masyarakat hukum adat (aspek keperdataan hak ulayat) (Sumardjono, 2007).

Sektor pertambangan mineral dan batubara misalnya masih menjadi salah satu penyumbang besar konflik dalam kerusakan lingkungan, perampasan tanah, pelanggaran Hak Asasi Manusia. Hal ini oleh masyarakat di asumsikan karena Negara memfasilitasi dan melakukan kekerasan bergelombang dari waktu ke waktu yang sistemik dan sistematis melalui produk UndangUndang (UU investasi, UU Minerba, UU Penyedian Tanah Untuk Pembangunan ). Selain itu keputusaan-keputusan regulatif turunannya yang muaranya adalah pemberian legitimasi dan hak-hak khusus kepada sektor pertambangan yang sudah lama dikenal sebagai pihak yang sering berseberangan dengan orang desa (petani, nelayan, dan pelaku ekonomi kecil). Bahwa tidak pernah ada penyelesaian yang struktural dan mendasar pada konflik-konflik sektor pertambangan mineral dan batubara. Dapat dikatakan hingga masa kini sektor pertambangan mineral dan batubara masih menjadi anak emas yang selalu dilindungi oleh negara.

Dengan memperhatikan fakta sosial interaksi masyarakat dengan hukum sebagaimana fokus tulisan ini, melihat konsekuensi dari pengaturan yang terpusat, segala ketentuan, prosedur dan mekanisme penegakan tidak mungkin dengan sendirinya diketahui oleh segenap lapisan masyarakat Indonesia yang begitu plural lagi heterogen, kemudian bagaimana hukum negara dengan sistem aturan yang umum, abstrak dan uniform itu 
dapat sampai, diterima pada masyarakat terutama masyarakat lokal. Maka Pada tulisan ini penulis berusaha mengurai satu pemikiran tentang Konflik Pembebasan Lahan Atas Tanah Ulayat Masyarakat Hukum adat yang di lakukan oleh perusahaan sebagai pelaku investasi yang menjalankan kegiatan usaha di bidang pertambangan mineral dan batubara.

\section{Tinjauan Umum Teori Konflik}

Dalam tulisan ini penulis mengunakan pilihan kosakata Konflik daripada pengunaan kata Sengketa dengan alasan konflik memberikan pengertian yang luas tentang pertentangan, ketidaksesuaian beraspek politik, ekonomi dan sosial budaya. Istilah konflik (conflict) dalam pendapat Webster, sebagaimana di kutip Sarjita menyatakan bahwa istilah konflik dalam bahasa aslinya berarti suatu "Perkelahian, peperangan atau perjuangan",. yaitu berupa konfrontasi fisik antara beberapa pihak. Yang kemudian artinya berkembang menjadi ketidak sepakatan yang tajam atau oposisi atas berbagai kepentingan, ide dan lain-lain (Sarjita, 2011;13). Konflik juga dapat diartikan adanya oposisi atau pertentangan pendapat antara orangorang, kelompok-kelopok atau organisasi-organisasi (Winardi, 2007;1). Selanjutnya Pengertian konflik dalam hukum tanah adalah Konflik adalah perbedaan nilai, kepentingan, pendapat dan atau persepsi antara warga atau kelompok masyarakat dan atau warga atau kelompok masyarakat dengan badan hukum (privat atau publik), masyarakat dengan masyarakat mengenai status penguasaan dan atau status kepemilikan dan atau status penggunaan atau pemanfaatan atas bidang tanah tertentu oleh pihak tertentu, atau status Keputusan Tata
Usaha Negara menyangkut penguasaan, pemilikan dan penggunaan atau pemanfaatan atas bidang tanah tertentu, serta mengandung aspek politik, ekonomi dan sosial budaya (Lampiran 01/Juknis/D.V/ 2007 Angka Romawi II angka 4 Keputusan Kepala Badan Pertanahan Nasional Nomor 34 Tahun 2007 tentang Petunjuk Teknis Penangan dan Penyelesaian Masalah Pertanahan).

Selanjutnya lebih luas dalam Bab Satu Ketentuan Umum Pasal 1 Butir 1 Undang-Undang Nomor 7 Tahun 2012 Tentang Penanganan Konflik Sosial pengertian konflik sosial adalah Perseteruan dan/atau benturan fisik dengan kekerasaan antara dua kelompok masyarakat atau lebih yang berlangsung dalam waktu tertentu dan berdampak luas yang mengakibatkan ketidakamanan dan disintegrasi sosial sehingga mengganggu stabilitas nasional dan menghambat pembangunan nasional.

\section{Penyebab Konflik dan Jenis Konflik}

Penyebab terjadinya konflik Menurut Dean G. Pruitt dan Jeffrey Z Rubin ada tiga faktor yakni (Sarjita; 2011) :

1. Tingkat aspirasi suatu pihak;

2. Persepsi satu pihak atas aspirasi pihak lain, dan

3. Tidak ditemukan alternatif yang bersifat intergratif.

Muncul dan berkembanganya Konflik biasanya mengikuti suatu pola yang teratur beberapa pola konflik menurut G.R Terry terbagi empat macam yakni :

1. Pertama-tama timbul suatu krisis tertentu.

2. Gejala Eskalasi ketidaksesuaian paham terjadi.

3. Konfrontasi menjadi pusat perhatian. 
4. Krisis selanjutnya di alihkan dalam arti.

Dalam memaknai konflik Loekman Soetrisno menyebutkan bahwa konflik tidak selalu bersifat disfungsional. Justru sebaliknya dengan terjadinya konflik dapat terjadi sesuatu yang fungsional. Artinya dapat menjadi wahana untuk mendorong terjadinya suatu perubahan menuju suatu kondisi yang lebih baik, oleh karenanya selanjutnya konflik di bedakan menjadi dua jenis yakni :

1. Konflik yang bersifat destruktif, hal ini terjadi apabila muncul konflik akan tetapi tidak disertai mekanisme meredam konflik.

2. Konflik yang bersifat Fungsional, yakni konflik yang menghasilkan perubahan atau konsensus baru yang bermuara pada perbaikan.

Selanjutnya Konflik di bedakan dari substansinya, yakni konflik hukum dan konflik kepentingan. Konflik hukum adalah konflik yang menyangkut perbedaan hak dan kewajiban. Konflik hukum ini berawal dari terjadinya pelanggaran atas hakhak seseorang atau terjadinya pelanggaran dalam pelaksanaan kewajiban. Berbeda dengan konflik kepentingan. Konflik kepentingan menyangkut perbedaan pandangan mengenai akses atas sesuatu hal, bisa tanah, kekayaan alam maupun sumber daya alam yang terkadung di dalamnya. Konflik menurut substansinya, ini dikenal adanya konflik hukum yang di dasarkan nilai. Suatu persoalan yang terjadi baru dapat di ketahui sebagai suatu konflik hukum di dasarkan pada nilai apabila konflik tersebut tidak dapat di selesaikan dengan cara litigasi maupun ADR seperti menyelesaikan keberadaan konflik hukum dan konflik kepentingan.
Dalam Undang-Undang Nomor 7 Tahun 2012 Tentang Penanganan Konflik Sosial Pasal 5 Konflik dapat bersumber dari :

a. Permasalahan yang berkaitan dengan politik, ekonomi, dan sosial budaya;

b. Perseteruan antarumat beragama dan/atau interumat beragama, antarsuku, dan antaretnis;

c. Sengketa batas wilayah desa, kabupaten/kota, dan/atau provinsi;

d. Sengketa sumber daya alam antar masyarakat dan/atau antar masyarakat dengan pelaku usaha; atau

e. Distribusi sumber daya alam yang tidak seimbang dalam masyarakat.

\section{Bentuk-Bentuk Konflik Dan Skala Konflik}

Adapun bentuk-bentuk konflik di lihat dari sifat konflik adalah dapat berwujud konflik tertutup (laten), mencuat (emerging), dan terbuka (manifest). Konflik tersembunyi (laten) di cirikan dengan adanya tekanantekanan yang tidak nampak atau tidak sepenuhnya berkembang dan belum terangkat ketingkat konflik. Seringkali masing-masing pihak tidak menyadari adanya konflik bahkan yang sifatnya sudah menjadi potensial. Konflik mencuat (emerging) adalah identifikasi perselisihan, kebanyakan permasalahan jelas, tapi proses negosiasi dan penyelesaian belum berkembang. Di sisi lain, di kenal pula istilah konflik terbuka (manifest). Konflik terbuka (manifest) adalah konflik yang terjadi di antara pihak-pihak yang berselisih secara aktif. Kedua belah pihak terlibat dalam perselisihan yang terjadi mungkin sudah mulai untuk bernegosiasi dan mungkin juga sudah mencapai jalan buntu 
(Diasari, 2010;109). Konflik di lihat dari skala konflik di masyarakat di bedakan kedalam konflik antar orang (interpersonal conflict), konflik antar kelompok (intergroup conflict) konflik antar kelompok dengan negara (vertical conflict) dan konflik antar negara (interstate conflict). Setiap perbedaan konflik memiliki latar belakang dan arah perkembangannya.

\section{Konflik Pertanahan Dalam Sektor Pertambangan Mineral dan Batubara}

Dalam proses investasi di sektor pertambangan mineral dan batubara, dimana bahan galian mineral berada di dalam permukaan bumi sehingga perlunya proses pengeluapasan kulit terluar bumi yakni tanah dan tentunya bersinggungan dengan pemilik hak atas tanah maka disini muncul perselisihan hukum akibat berlakunya dua kaidah atau lebih pilihan hukum dalam satu peristiwa hukum dalam hal ini pemilik hak atas tanah bisa saja orang perorangan, komunitas adat, bahkan badan usaha swasta (seperti HGU Perkebunan sawit), dalam kaitan hak atas tanah dalam wilayah masyarakat adat yang disebut sebagai tanah adat, maka terjadinya percampuran hukum yakni hukum adat, hukum agraria dalam hal ini adalah hukum tanah dan hukum pertambangan. Terjadi Konflik Hukum Negara dengan hukum adat adalah bentuk kesenjangan atau bahkan konflik kebudayaan antara pembentuk dan pengembang hukum, tanpa upaya mendamaikan keduanya maka dalam banyak hal hukum negara tidak berjalan efektif (Soetandyo, 2011;4).

\section{Penyebab Konflik}

Pada umumnya konflik pengelolaan sumber daya alam mineral dan batubara memiliki penyebab ganda, biasanya kombinasi-kombinasi dari masalah-masalah dalam hubungan antara pihak yang bertikai kemudian mengarah kepada konflik yang terbuka. Karena seringkali menjadi rumit, maka sangat penting untuk melakukan identifikasi pusat.

Dari pengalaman empirik di berbagai daerah di Indonesia, dapat di nyatakan bahwa sumber pokok konflik atas pengelolaan sumber daya alam mineral dan batubara adalah :

1. Konflik yang bersifat kultural, dengan melibatkan unsur-unsur lainnya seperti konflik struktural (terjadi karena adanya ketimpangan untuk melakukan akses dan kontrol terhadap sumber daya);

2. Konflik kepentingan (disebabkan oleh persaingan kepentingan yang di rasakan atau yang secara nyata memang tidak bersesuaian);

3. Konflik nilai (disebabkan karena adanya orang yang berusaha untuk memaksakan suatu nilai kepada yang lainnya, atau mengklaim suatu sistem nilai yang eksklusif dimana di dalamnya tidak di mungkinkan adanya percabangan kepercayaan);

4. Konflik hubungan antar manusia (terjadi karena adanya emosi-emosi negatif yang kuat, salah persepsi atau stireotif, salah komunikasi, atau tingkah laku negatif yang berulang/repetitif), dan konflik data (terjadi ketika orang kekurangan informasi yang di butuhkan untuk mengambil keputusan yang bijaksana, dapat memberi iformasi yang salah, tidak sepakat mengenai apa saja data yang relevan, menterjemahkan informasi dengan cara yang berbeda atau memakai tata cara pengkajian yang berbeda) (Soetandyo, 2011;114).

\section{Bentuk dan Jenis Konflik}

Konflik dalam pengelolaan sumber daya alam mineral dan batubara merupakan rangkaian yang tidak dapat 
terpisahkan dalam hubungan agraris dalam sistem apapun. Walaupun demikian tidak berarti konflik-konflik yang muncul tersebut sama bentuknya. Setiap priode menunjukan bentuk konflik yang berbeda dan sangat bergantung kepada kondisi hubungan agraris yang ada, serta sistem dan kebijakan yang berlaku dalam kurun waktu tersebut.

Dalam kajian Disertasi, hasil penelitian dan observasi yang dilakukan Salim HS, Jenis sengketa dalam pelaksaan kegiatan pertambangan, meliputi (Salim Hs, 2014;215):

1. Sengketa antara Indigeneos people dengan perusahaan tambang

2. Sengketa pencemaran Lingkungan;

3. Sengketa hak atas tanah

4. Sengketa divestasi saham;

5. Sengketa program community development

6. Sengketa wilayah kontrak karya, dan

7. Sengketa perburuhan.

\section{Obyek Konflik}

Dalam hukum adat, hak penguasaan atas tanah yang tertinggi adalah hak ulayat yang mengandung unsur yang beraspek hukum keperdataan dan hukum publik. Subjek hak ulayat adalah masyarakat hukum adat, baik teritorial maupun genealogik, sebagai bentuk bersama warganya. Tanah ulayat adalah tanah bersama para warga masyarakat hukum adat yang bersangkutan yang pada umumnya batas wilayah hak adat tidak dapat ditentukan secara pasti. Hak ulayat mempunyai kekuatan yang berlaku kedalam dan keluar. Kedalam, berhubungan dengan para warganya, Sedangkan kekuatan berlaku keluar dalam hubungan dengan bukan anggota masyarakat hukum adatnya yang disebut dengan "orang asing" atau "orang luar".

Obyek konflik adalah lahan-lahan dalam wilayah tanah Ulayat yang akan dibebaskan untuk kepentingan investasi di sektor pertambangan mineral dan batubara yang umumnya adalah tanah adat yang disebut tanah ulayat (ulayat umum/maupun warisan kelompok persekutuan warga adat dan perorangan. Terkait dengan Tulisan ini mengkaji penyebab konflik horzontal yang terjadi antar masyarakat hukum adat dengan perusahan yang berinvestasi di sektor pertambangan mineral dan batubara yakni konflik mengenai perbedaan nilai, kepentingan, pendapat dan/atau persepsi antara warga atau kelompok masyarakat atau warga atau kelompok masyarakat mengenai status penguasaan dan/atau kepemilikan dan/atau status pengunaan atau pemanfaatan atas bidang tanah tertentu oleh pihak tertentu terkait hak atas tanah atau lahan adat yang masuk dalam wilayah ijin usaha pertambangan mineral dan batubara.

\section{Aktor Konflik}

Menurut Supandi, konflik dan sengketa pertanahan jika ditinjau dari subyek yang bersengketa, dapat dikelompokkan ke dalam 3 macam yaitu (Munsyarief, 2012;5):

1. Sengketa tanah antar warga;

2. Sengketa tanah antara Pemerintah Daerah dengan warga setempat;

3. Sengketa yang berkaitan dengan pengelolaan sumber daya alam.

Aktor Konflik Pembebasan Lahan di wilayah Tanah Ulayat Masyarakat Hukum adat yang di lakukan oleh perusahaan sebagai pelaku investasi yang menjalankan kegiatan usaha di bidang pertambangan mineral dan batubara Beberapa pihak yang terlibat 
dalam konflik ini merupakan mereka yang mempunyai andil besar, terlibat aktif dan berkepentingan dalam konflik lahan dalam pengelolaan sumber daya alam mineral dan batubara, yakni :

\section{a. Masyarakat Hukum Adat}

Dilihat dari perkembangan hidup manusia, terjadinya hukum itu mulai dari pribadi manusia yang diberi Tuhan akal pikiran dan perilaku. Perilaku yang terus menerus dilakukan perorangan menimbulkan kebiasaan pribadi. Apabila kebiasaan pribadi itu ditiru orang lain, maka ia akan menjadi kebiasaan orang itu, lambat laun diantara orang yang satu dan orang lain dalam kesatuan masyarakat ikut pula melakukan kebiasaan tersebut. Kemudian apabila seluruh anggota masyarakat melakukan kebiasaan tadi, maka lambat laun akan menjadi adat dari masyarakat tersebut.

Hukum adat adalah adat yang diterima dan harus dilaksanakan dalam masyarakat yang bersangkutan, untuk dapat mempertahankan pelaksanaan hukum adat itu agar tidak terjadi penyimpangan atau pelanggaran, maka diantara anggota masyarakat ada yang diserahi tugas mengawasinya, dengan demikian lambat laun petugas-petugas adat ini diangkat menjadi kepala adat (Setiady, 2008;1).

Prof. Dr. Barend Ter Haar Bzn, dalam pidato dies natalis RHS 1930 dengan judul "Peradilan Landraad Berdasarkan Hukum Tidak Tertulis", menyatakan :

"Hukum adat lahir dan di pelihara oleh keputusan-keputusan adat. keputusan para masyarakat hukum terutama keputusan berwibawa dari kepala-kepala rakyat yang membantu pelaksanaan perbuatan-perbuatan hukum dalam hal pertentangan kepentingan keputusan para hakim yang bertugas mengadili sengketa sepanjang keputusan-keputusan itu, karena kesewenangan atau kurang pengertian tidak bertentangan dengan keyakinan hukum rakayat melainkan senafas seirama dengan kesadaran tersebut diterima/ diakui atau setidak-tidaknya ditoleransi olehnya".

Adat dan hukum adat kemudian secara historis filosifis dianggap sebagai suatu perwujudan atau pencerminan kepribadian suatu bangsa dan merupakan penjelmaan dari jiwa bangsa (Volkgeist) suatu masyarakat Negara yang bersangkutan dari zaman ke zaman.

Prof. Hilman Hadikusuma menegaskan bahwa hukum adat Indonesia yang normatif pada umumnya menunjukan corak-corak sebagai berikut

1. Tradisional

Artinya bersifat turuntemurun dari zaman nenek moyang sampai anak cucu cicit sekarang dimana keadaannya masih berlaku dan tetap dipertahankan oleh masyarakat yang bersangkutan.

2. Keagamaan (magis-relegius) Artinya perilaku hukum atau kaidah-kaidah hukumnya berkaitan dengan kepercayaan terhadap yang gaib dan atau berdasarkan ajaran keTuhanan Yang Maha Esa.

3. Kebersamaaan

Artinya lebih mengutamakan kepentingan bersama dimana kepentingan pribadi itu diliputi kepentingan bersama.

4. Konkrit dan visual

Artinya hukum adat adalah kongkrit artinya jelas dan nyata, berwujud, visual artinya dapat dilihat, dapat terlihat, 
terbuka, tidak sembunyi. Jadi sifat hubungan hukum yang berlaku dalam hukum adat itu adalah terang dan tunai, tidak samar-samar, terang disaksikan, diketahui dan didengar orang lain, dan tampak Ijab Kabul (serah terimanya).

5. Terbuka dan sederhana

Artinya, dapat menerima masuknya unsur-unsur yang datang dari luar asal tidak bertentangan dengan jiwa hukum adat itu sendiri, sederhana, artinya, bersahaja tidak rumit, tidak banyak administrasinya, bahkan kebanyakan tidak tertuis mudah dimengerti dan dilaksanakan berdasarkan saling percaya mempercayai.

6. Dapat berubah dan menyesuaikan

7. Tidak dikodifikasi

8. Musyawarah dan mufakat.

Selanjutnya berbicara mengenai sistem hukum adat ini Prof. Dr. Seopomo, menyebutnya sebagai berikut :

"Tiap-tiap hukum merupakan suatu sistem yaitu peraturanperaturan merupakan dasar suatu kebulatan berdasarkan atas kesatuan alam pikiran, begitupun hukum adat. Sistem hukum adat bersendi atas dasar-dasar alam pikiran bangsa Indonesia yang tidak sama dengan alam pikiran yang menguasai sistem hukum barat. Untuk dapat sadar akan sistem hukum adat orang harus menyelami dasar-dasar alam pikiran yang hidup didalam masyarakat Indonesia".

Kalau kita perhatikan susunan pergaulan hidup di Indonesia pada taraf kehidupan rakyat maka akan melihat adanya pengelompokkan orang-orang yang bertindak sebagai kesatuan baik keluar maupun ke dalam. Tiap-tiap orang yang ada dalam kelompok tersebut merasa dirinya sebagai anggota kelompok itu dan tiap-tiap anggota menghayati keanggotaanya di dalam kelompok yang bersangkutan. Tiap-tiap kelompok pada umumnya berkeyakinan bahwa tindakan seseorang anggota tidak hanya akan membawa akibat bagi dirinya sendiri saja melainkan akan dirasakan oleh anggota-anggota kelompok lainnya. Tidak ada seorangpun dari mereka yang mempunyai pikiran akan kemungkinan membubarkan kelompok dimaksud. Tiap-tiap kelompok itu sebagai suatu kesatuan dan mempunyai pemimpin sendiri serta mempunyai kekayaan sendiri. Tiap-tiap kelompok mempunyai wilayah tertentu diatas dan didalam batas-batas wilayah itu kelompok yang bersangkutan menjalankan kehidupannya, kelompok yang demikian dinamakan persekutuan hukum atau masyarakat hukum. Persekutuan hukum atau masyarakat hukum (rechtsgemeenschap) itu adalah : sekelompok orang-orang yang terikat sebagai satu kesatuaan dalam susunan yang teratur, yang bersifat abadi dan memiliki pimpinan dan kekayaan sendiri baik berwujud maupun tidak berwujud dan mendiami atau hidup diatas wilayah tertentu.

Prof.Dr. Ter haar Bzn merumuskan masyarakat hukum adat sebagai :

“...ge ordende groepen van blijvend karakter met eigen bewind en eigen materiel vermogen". (terjemahan bebas “... kelompok-kelompok teratur yang sifatnya ajek dengan pemerintahan sendiri yang memiliki benda-benda materil maupun immaterial") (Setiady, 2008;76). 
Secara teoritis, pengertian masyarakat hukum dan masyarakat hukum adat berbeda, Kusumadi Pujosewojo mengartikan:

"Masyarakat hukum sebagai suatu masyarakat yang menetapkan, terikat dan tunduk pada tata hukum sendiri. Sedangkan masyarakat hukum adat adalah masyarakat yang timbul spontan di wilayah tertentu, yang berdirinya ditetapkan dan diperintahkan oleh penguasa yang lebih tinggi atau penguasa lainnya, dengan rasa solidaritas yang sangat besar di antara anggotanya, yang memandang bukan anggota masyarakat sebagai orang luar dan mengunakan wilayahnya sebagai sumber kekayaan yang hanya dapat dimanfaatkan sepenuhnya oleh anggotanya. Pemanfaatan oleh orang luar harus dengan izin dan pemberian imbalan tertentu, berupa rekognisi dan lain-lain" (Sumardjono, 2007;5).

Demikian dapat disimpulkan bahwa sebagaimana yang ditegaskan oleh. Prof. Bushar Muhammad, Inti dari persekutuan hukum adat masyarakat hukum adalah :

1. Kesatuan masyarakat yang teratur

2. Menetap didaerah tertentu

3. Mempunyai penguasapenguasa, dan

4. Mempunyai kekayaan yang berwujud ataupun tidak berwujud dimana para anggota kesatuan masing-masing mengalami kehidupan dalam masyarakat sebagai hak yang wajar menurut kodrat alam dan tidak seorangpun diantara mereka mempunya pikiran atau kecendrungan untuk membubarkan ikatan yang telah tumbuh itu atau meninggalkannya dalam arti melepaskan diri dari ikatan itu selama-lamanya (Setiady;56).

Bahwa hukum tanah nasional disusun berdasarkan hukum adat tentang tanah, dinyatakan dalam konsiderans Undang-Undang Pokok Agraria, dalam penjelasan umum angka III (1) Undang-Undang Pokok Agraria. Sehingga untuk memenuhi aspirasi dari berbagai elemen masyarakat terkait dengan banyaknya pemasalahan yang terjadi di dalam masyarakat hukum adat akibat dari kekayaan adat yang mereka miliki yaitu hak atas tanah adat, sehingga Menteri Negara Agraria mengeluarkan keputusan mengenai pedoman penyelesaiaan masalah hak ulayat masyarakat hukum adat dimana di dalamnya termuat hal-hal yang terkait dengan kepentingan masyarakat hukum adat. Salah satunya adalah Kriteriakriteria penentu agar dapat diakui sebagai masyarakat hukum adat (Pasal 2 Peraturan Menteri Negara Agraria Nomor 5 Tahun 1999) Tentang Pedoman Penyelesaian Masalah Hak Ulayat Masyarakat Hukum Adat, yakni :

1. Masih adanya suatu kelompok masyarakat hukum adat yang memenuhi ciri-ciri tertentu subyek hak ulayat;

2. Masih adanya tanah yang merupakan wilayah dengan batasan-batasan tertentu sebagai lebensraum yang merupakan obyek hak ulayat;

3. Masih adanya tatanan hukum adat mengenai kepengurusan, pengurusan, penggunaan tanah ulayat yang berlaku dan ditaati oleh masyarakat hukum adat, yaitu lembaga adat yang meliputi kepala adat, sesepuh/ tetua-tetua adat; 
4. Adanya kewenangan masyarakat hukum adat untuk melakukan tindakaan-tindakan tertentu sebagaimana diuraikan diatas.

Sehingga dapat penulis simpulkan bahwa Pemilik tanah Adat dalam pengertian hukum agraria di sebut tanah ulayat adalah Seluruh Masyarakat Adat yang tergabung dalam kawasan teritorial tertentu (kepemilikan komunal), seluruh masyarakat adat ini yang berkepentingan terhadap keberadaan Tanah Ulayat, yang bertanggung Jawab penuh atas tuntutan dari pihak manapun, masyarakat Adat yang di Maksud adalah keseluruhan masyarakat adat termasuk para tetua-tetua Adat yang dalam pengertian Modern disebut Tokoh Adat.

\section{b. Lembaga Adat}

Lembaga adat adalah sebuah organisasi kemasyarakatan, baik yang disengaja dibentuk maupun secara wajar telah tumbuh dan berkembang di dalam sejarah masyarakat yang bersangkutan atau dalam suatu masyarakat hukum adat tertentu dengan wilayah hukum dan hak atas harta kekayaan didalam wilayah hukum adat tersebut, serta berhak dan berwenang mengatur, mengurus dan menyelesaikan berbagai permasalahan kehidupan yang berkaitan dengan dan mengacu pada adat istiadat dan hukum adat yang berlaku. Pemegang Hak Ulayat yang bertanggung jawab disebut sebagai aktor dalam hal ini karena mengkoordinir rencana pengelolaan hak ulayat adalah Kepala Adat, Sebagai Lembaga Sah yang di pilih oleh seluruh masyarakat adat, kepala adat diberikan hak dan wewenang untuk melakukan tindakan kepengurusan, membina, mengelola, bertindak kedalam dan keluar menyelesaikan persoalanpersoalan yang terjadi didalam masyarakat adat itu sendiri maupun berkaitan dengan pihak luar sesuai dengan kaidah, adat istiadat setempat di seluruh wilayah adat yang berada dalam kewenanganya.

\section{Investor dalam bentuk Badan Hukum yang menjalankan kegiatan usaha pertambangan Mineral dan Batubara}

Hukum investasi tidak bisa dipisahkan dari pelaku investasi yang disebut Investor baik itu perorangan maupun berupa badan-badan usaha yang bergerak dalam kepentingan bisnis, pelakunya bisnis disebut pengusaha adalah orang menjalankan perusahaan, yaitu mengelola perusahaan, baik mengelola sendiri, mengelola dengan perentaraan orang lain maupun dengan bantuan orang lain. Dalam sistem perekonomian nasional Indonesia di akui bahwa perusahaan merupakan bagian pilar yang menentukan keberhasilan pembangunan ekonomi yang turut berperan meningkatkan kesejahteraan masyarakat. Istilah perusahan lahir sebagai wujud perkembangan yang terjadi dalam dunia usaha, istilah perusahaan merupakan istilah ekonomi yang dimasukan kedalam hukum, khususnya hukum dagang, sehingga diakomodir mula-mula dalam kitab undang-undang hukum dagang (KUHD). Perusahaan berupa organisasi usaha (onderneming, company), yang mengambil suatu bentuk usaha yang di kenal di dalam perundang-undangan.

Apabila di lihat dari obyek usahanya dan tata perniagaanya, hukum perusahaan termasuk dalam lapangan hukum perdata, khususnya dalam bidang hukum harta kekayaan, dalam kegiatan ekonominya pada umumnya, maka hukum perusahaan termasuk didalam cakupan hukum ekonomi (Mulhadi, 2010;21). Bentuk-bentuk badan usaha atau badan perusahan di Indonesia beragam jumlahnya, sebagian besar dari bentuk-bentuk badan usaha tersebut 
merupakan peninggalan masa lalu (pemerintah Belanda), diantaranya ada yang diganti dengan sebutan dalam bahasa Indonesia dan sebagian tetap mengunakan nama aslinya. Beberapa bentuk-bentuk perusahan di Indonesia secara teoritis maupun ditinjau dari status hukum, bentuk hukum perusahaan memiliki dua bentuk yakni (Mulhadi, 2010;25) :

1. Bentuk usaha atau perusahan bukan badan hukum, meliputi :

a. Perusahaan perseorangan, yang wujud berbentuk perusahaan dagang (PD) atau usaha dagang (UD).

b. Persekutuan yang wujudnya terdiri dari bentuk-bentuk seperti

a. Persekutuan Perdata (Maatschap)

b. Persekutuan Firma ( $\mathrm{Fa}$ )

c. Persekutuan Komanditer (CV)

2. Bentuk usaha atau perusahaan Berbadan hukum meliputi :

a. Perusahaan Maskapai Indonesia (IMA)

b. Perseroan Terbatas (PT)

c. Koperasi

d. Badan Usaha Milik Negara (BUMN)

a. Perusahaan perseroan (persero)

b. Perusahan umum (perum).

Menurut hukum suatu perusahaan didirikan dengan syarat-syarat yang ditentukan oleh undang-undang untuk setiap bentuk yang dipilih. Dengan demikian, syarat mendirikan perusahaan berkaitan erat dengan bentuk usaha yang dipilih (Sidabalok, 2012;7). Perusahan menjalankan kegiatan usahanya secara tetap, terus menerus, tidak putus-putus, bekerja secara terang-terangan dan menjalankan usaha dengan tujuan utama memperoleh keuntungan dan atau laba yang merupakan hasil kegiatan perusahan, berupa nilai lebih yang diperoleh dari modal yang ditanam, dengan tata pembukuan dan pencatatan atas aktivitas yang dilakukan (Sidabalok, 2012;9).
Pelaku investasi yang disebut Investor baik itu perorangan maupun berupa badan-badan usaha yang bergerak dalam kepentingan bisnis, pelakunya bisnis disebut pengusaha adalah orang menjalankan perusahaan, yaitu mengelola perusahaan, baik mengelola sendiri, mengelola dengan perentaraan orang lain maupun dengan bantuan orang lain (Sidabalok, 2012;10). Usaha investasi dalam bidang pertambangan mineral batubara termasuk jenis investasi langsung (direct investment) yakni investasi yang dilaksanakan dengan kepemilikan proyek yang keliatan wujudnya. Suatu kegiatan yang dilakukan dengan pengalian kedalam tanah (bumi) untuk mendapat sesuatu berupa hasil tambang (mineral, minyak, gas bumi, dan batu bara) (Supramono, 2012;6). Adapun pengertian pertambangan dalam Pasal 1 Angka 1 Undang-Undang Nomor 4 Tahun 2009 adalah sebagian atau seluruh tahapan kegiatan dalam rangka penelitian, pengelolaan dan pengusahaan mineral dan batu bara yang meliputi penyelidikan umum, eksplorasi, studi kelayakan, konstruksi, penambangan, pengelolaan dan permurnian, pengangkutan dan penjualan, serta kegiatan pascatambang. Atas dasar ijin-ijin dari pemerintah pihak Investor dalam bentuk orang perorangan dan badan hukum Perusahan inilah yang berkepentingan terhadap lahan-lahan yang berada dibawah penguasaan masyarakat adat.

\section{d. Pemerintah Pusat Dan \\ Pemerintah Daerah}

Menurut keterangan dalam Bab I Ketentuan Umum Pasal 1 UndangUndang Nomor 4 Tahun 2009 tentang Pertambangan Mineral dan Batubara, pemerintah yang dimaksud adalah Pemerintah Pusat, yang selanjutnya disebut Pemerintah adalah Presiden 
Republik Indonesia yang memegang kekuasaan Pemerintahan Negara Republik Indonesia sebagaimana dimaksud dalam Undang-Undang Dasar Negara Republik Indonesia Tahun 1945, Menteri adalah menteri yang menyelenggarakan urusan pemerintahari di bidang pertambangan mineral dan batubara Pemerintah daerah adalah Gubernur, Bupati atau Walikota, dan perangkat daerah sebagai unsur penyelenggaraan pemerintahan daerah,

Pemerintah dalam hal ini disebut adalah pemerintah pusat dan Daerah, hal ini karena melihat hukum investasi disektor pertambangan mineral dan batubara, diatur mengenai hak dan kewenangan pemerintah pusat dan daerah sesuai dengan jenis ijin usaha pertambangan.

\section{Penutup}

\section{Simpulan}

Dalam UUPA menyatakan hukum agraria nasional berlandaskan hukum adat, dalam hal ini hukum adat yang di konstruksi oleh hukum negara. UndangUndang Pokok Agraria menunjukan konsep pluralisme dengan membahas konstruksi undang-undang pokok agraria terhadap hukum, menunjukan bahwa dalam relasi antara hukum negara dan hukum adat sangat dimungkinkan upaya mengkontruksikan atau mendekonstruksikan hukum adat sesuai kepentingan negara. Hal yang sangat tepat menyelesaikan konflik dengan menggunakan adat lokal atau kearifan lokal yakni berperannya lembaga karena selama ini sudah membudaya dalam masyarakat. Oleh karena kearifan lokal adalah sesuatu yang sudah mengakar dan biasanya tidak hanya berorientasi profit semata, tetapi juga berorientasi sakral sehingga pelaksanaannya bisa lebih cepat dan mudah diterima oleh masyarakat. Dengan adat lokal ini diharapkan resolusi konflik bisa cepat terwujud, bisa diterima semua kelompok sehingga tidak ada lagi konflik laten yang tersembunyi dalam masyarakat.

\section{Saran}

Pemerintah perlu mengakomodir lembaga-lembaga adat masuk kedalam sistem legal formal, yaitu menempatkan lembaga-lembaga adat dalam perundang-undangan seperti Keistimewaan Aceh, Undang-Undang otonomi khusus Nanggroe Aceh Darussalam, dan Undang-Undang Pemerintah Aceh, dan di beberapa daerah lain lembaga adat di masukan pengaturannya di dalam peraturan daerah (PERDA).

\section{Daftar Pustaka \\ Buku}

Diasari, Ratih, 2010, Pemetaan Konflik Pertanahan Masyarakat Hukum Adat Terhadap Tanah Ulayat di Kabupaten Sorong Selatan, Skripsi, Fakultas Hukum UGM.

Husni, Anang, 2009, Hukum, Birokrasi dan Budaya, Genta Publishing, Yogyakarta.

Irianto, Sulistyowati, 2000, Hukum dan Kemajemukan Budaya, Sumbangan Karangan Untuk Menyambut Hari Ulang Tahun ke 70 Prof. Dr.T.O. Ihromi, yayasan Obor Indonesia, Jakarta

Mulhadi, 2010, Hukum Perusahaan Bentuk-Bentuk Badan Usaha di Indonesia, Ghalia Indonesia, Bogor. Munsyarief , 2012, Jurnal Pertanahan, Menuju Percepatan Penyelesaian Sengketa dan Konflik Pertanahan, Alternatif Penyelesaian Sengketa, Konflik Dan Perkara Pertanahan Melalui Pembentukan UndangUndang Pertanahan dan Peradilan Pertanahan. 
Rahardjo, Satjipto, 2009, Membangun dan Merombak Hukum Indonesia, Sebuah Pendekatan Lintas Displin, Genta Publishing, Yogyakarta.

Saidin, 2000, Hukum Dan Kemajemukan Budaya, Sumbangan Karangan Untuk Menyambut Hari Ulang Tahun Ke 70 Prof. Dr.T.O. Ihromi, Yayasan Obor Indonesia, Jakarta.

Salim Hs, 2014, Hukum Pertambangan Mineral dan batu bara, Siar Grafika, Jakarta Timur.

Sarjita, 2011, Strategi Dan Manajemen Resolusi Konflik, Sengketa dan perkara pertanahan untuk keamanan di bidang Investasi, Mitra Amanah Publishing, Yogyakarta.

Setiady, Tolib, 2008, Inti Sari Hukum Adat Indonesia, Dalam Kajian Kepustakan, Alfabeta, Bandung.

Sidabalok, Janus, 2012, Hukum Perusahaan Analisis terhadap pengaturan peran perusahaan dalam pembangunan ekonomi nasional di Indonesia, Nuansa Aulia, Bandung.
Soetandyo, et al., 2011, Untuk Apa Pluralisme Hukum, Epistema Institute, Jakarta.

Supramono, Gatot, 2012, Hukum Pertambangan Mineral Dan Batu Bara Di Indonesia, Rineka Cipta.

Winardi, 2007, Manajement Konflik (Konflik perubahan dan pengembangan), Mandar Maju, Bandung.

\section{Peraturan Perundang-Undangan}

Lampiran 01/Juknis/D.V/ 2007 Angka Romawi II angka 4 Keputusan Kepala Badan Pertanahan Nasional Nomor 34 Tahun 2007 tentang Petunjuk Teknis Penangan dan Penyelesaian Masalah Pertanahan.

\section{Media Massa/Koran}

Sumardjono, Maria, 2007, Kebijakan Pertanahan Antara Regulasi dan Implementasi, Kompas, Jakarta.

Sumardjono, Maria S.W., 2007, Kebijakan Pertanahan Antara Regulasi dan Implementasi, KOMPAS, Jakarta.

Sumardjono, Maria S.W., 2007, Tanah Dalam Perspektif Hak Ekonomi, Sosial dan Budaya, KOMPAS, Jakarta. 